\title{
A STUDY OF HYDRO RESOURCE MANAGEMENT AT EARLY HISTORIC SITE OF KANHERI, MAHARASHTRA: AN ENGINEERING PERSPECTIVE
}

\author{
Reena Joshi \\ Ms., Deccan College Post Graduation \& Research Institute, INDIA, reena.joshi2007@gmail.com
}

\begin{abstract}
Kanheri known as "Krishnagiri" or "Krishnasaila" in ancient inscriptions is located (19 $19^{\circ} 13^{\prime} \mathrm{N}$. and $\left.72^{\circ} 59^{\prime} \mathrm{E}\right)$ $10 \mathrm{Km}$ to south east of Borivali, a suburb of metropolitan Mumbai. It is a rock cut cave complex comprising of more than 110 Buddhist caves including chaityas, Viharas, Stupas, cells etc. This site culturally dates back from $2^{\text {nd }}$ century C.E to late $11^{\text {th }}$ Century C.E. Kanheri is distinctively known for its sustainability as well as certain peculiar features like site's multi-storied settlement pattern, satellite settlements, developed water conservation system, brick memorial gallery, connectivity through rock cut steps etc. Apart from this, Kanheri stands out to be unique due to its well-developed hydro resource system which was operational for more than a millennium. The water must have been an important commodity for the ancient monks so as today. Thus a system that regulates the resourceful conservation of water during scarcity periods can be noticed at site. The prominent elements comprising of this hydro resource system are cisterns, large tanks, a dam/ reservoir, water channels and its connectivity. There are some inscriptions found associated to donations of these cisterns and tanks suggests us a methodology for dating numerous caves and its cisterns respectively.

A study of water management at the site considering the epigraphical, social and religious aspects has been attempted by various scholars till now. But this paper exclusively aims at investigating the significance of ancient hydraulic mechanisms that are evident at site, intends to prove the ancient administrative structure of monastery which regulated the advancement of engineering to sustain their livelihood. Thus an attempt will be made to study the mechanism behind this system considering the scientific and mechanical perspectives with the use of engineering principles.
\end{abstract}

Keywords: Kanheri, Buddhist caves, mechanism, hydraulic engineering, rock-cut architecture.

\section{INTRODUCTION}

Kanheri known as "Krishnagiri" or "Krishnasaila" in ancient inscriptions is located $\left(19^{\circ} 13^{\circ} \mathrm{N}\right.$. and $\left.72^{\circ} 59^{\circ} \mathrm{E}\right)$ $10 \mathrm{Km}$ to south east of Borivali, a suburb of metropolitan Mumbai. It is a rock cut cave complex of more than 110 Buddhist caves. The name Krishnagiri is a Sanskrit name given to site due to its geological properties. In Sanskrit, "Krishna" means "Black" and "Giri" means "mountain" Thus Krishnagiri literally means Black Mountain. The black mountain is a part of Deccan basalt ranges in western Maharashtra. The site comprises of various architectural elements such as Chaityagrihas, Viharas, Madapas etc. Buddha passed an ordinance of "Varsha-Vasa"1, which intended a temporary settlement for monks during the time of rainy

\footnotetext{
${ }^{1}$ It is mentioned in Buddhist texts, Vinayapitaka contains rules for monks prescribed by Buddha
} 
season. Monks were not allowed to beg alms during this period of climatic season. This initiated the activity of carving caves out of rock for temporary settlement of monks. This is only site like famous Ajanta caves ${ }^{2}$ which was habituated for more than 1000 years. Kanheri stands unique not only because of its sustainability but due to its peculiar features like developed water management system, satellite settlements, brick memorial gallery, connectivity through rock cut steps etc. Apart from this the location of site proved to be strategic from trade point of view since it is not far from ancient port town Sopara and Chaul. Ancient cave sites like Magathane, Jivdan, Ambivali, Elephanta and Mahakali are within the periphery of Kanheri (Pandit 2003, pg 382). Few of this places are mentioned in the inscriptions of Kanheri itself. The site's name Kanheri also appears in the inscriptions of cave no. 12, 21, 26 etc. of site itself. The excavations at Kanheri started in the early phase of Hinayana period and were extensively remodeled and sculpted during Mahayana period.

\section{CULTURAL CHRONOLOGY}

The caves present at Kanheri have been divided on the basis of their chronology, features and variations in sculpting technology. On the basis of epigraphical as well as architectural evidences found at the site, the caves are divided chronologically into three cultural periods represented in Table.1.

Table.1 Historical chronology with reference to Dynasty

\begin{tabular}{|c|c|c|}
\hline $\begin{array}{c}\text { Chronological } \\
\text { Period }\end{array}$ & $\begin{array}{c}\text { Historical } \\
\text { Timeframe }\end{array}$ & Dynasty \\
\hline Period 1 & $2^{\text {nd }}$ C.E to $4^{\text {th }}$ C.E & Satavahana, Vakataka \\
\hline Period 2 & $5^{\text {th }}$ C.E to $6^{\text {th }}$ C.E & Traikutaka \\
\hline Period 3 & $7^{\text {th }}$ C.E to $11^{\text {th }}$ C.E & Rashtrakuta, Shilahara \\
\hline
\end{tabular}

Kanheri thus has sustained its importance considerably for a large time frame. The site has witnessed an evolution from its beginning to decline. This is evident from the architectural and provisional changes that took place in different cultural periods. This monastery might have accommodated thousands of monks in its flourishing phase. This statement can be supported by looking at the well-developed water storage system existing at the site. The main objective of this research aims at examining the engineering behind the given state of technology applied by the early engineers at Kanheri. (Fig 1)

The rock cut caves at the site are scattered on 3 hills adjoining each other namely the Southern, Northern and Eastern hill respectively. The southern hill and the northern hill are divided by a water stream flowing between them. Most of the caves are located facing to this water stream on both the hills. The caves on southern hill are facing to north and the caves on northern hill are facing to south. There are two water bodies in the vicinity of Kanheri namely, Tulsi and Vihar lakes. But to the surprise these are artificially constructed in $19^{\text {th }}$ century and are not part of water system of ancient Kanheri.

\section{GEOLOGICAL LANDSCAPE}

Kanheri is located in the dense forest of Sanjay Gandhi National Park, Borivali. As mentioned earlier, these rock cut caves are scattered on three hills mainly Southern, Eastern and Northern. The elevation of these hills is not more than 600 meters. Within the vicinity of these hills, there are two artificial lakes namely Tulsi and Vihar. These two lakes are one of the major source of water supply for current population on Bombay. However, these lakes were artificially constructed in late 90's. The hills of contributes to breccia agglomerate rock formation. Agglomerate is a coarse accumulation of large blocks of volcanic material found near volcanic vents and within volcanic conduits, where they may be associated with pyroclastic or intrusive volcanic breccia ${ }^{3}$. This basaltic formation created a favorable opportunity for hewing purpose for the ancient Buddhist monks. Apart from the lakes, the current topography of the landscape does not exhibit any other source of water to Kanheri. Thus it is evident that there was no source available other than rain water in the ancient times on the hills of Kanheri. This represents the scarcity of water despite of Kanheri being located in a heavy rainfall region. A systematic drainage management survey of Kanheri and nearby landscape should be done to understand the drainage pattern of the site.

\footnotetext{
${ }^{2}$ Period of Ajanta dates back from 1st C.E to 10th C.E.

${ }^{3}$ It is a rock composed of broken fragments of minerals or rock cemented together by a fine-grained matrix.
} 


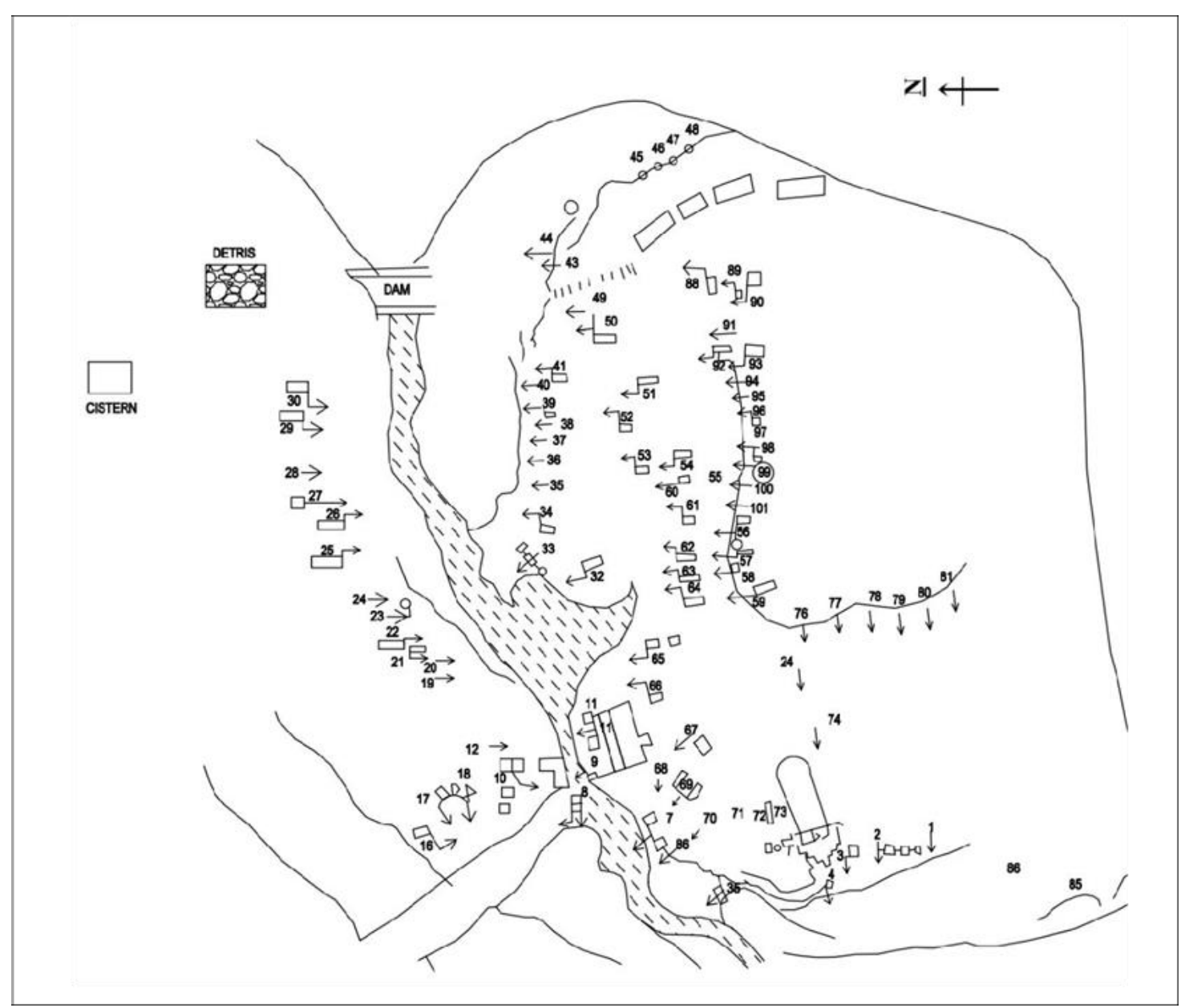

Fig.1 Map of Cisterns respective to their cave numbers.

\section{DATA AND METHODOLOGY}

As mentioned earlier there are more than 110 caves under the Kanheri complex. Almost every alternate cave has a cistern or two. A systematic survey was conducted by plotting most possible cisterns considering their location and the cave. Among the total 110 caves, 84 caves including 65 cisterns and tanks have been included as data in this study. Rest of the caves had some or the other kind of limitation to survey. Hence those are not included in this study. A topographic survey has also been done to study the water bodies around the site. The survey revealed that most of the cisterns are carved underground keeping its mouth the only visible access to the cistern. Due to this, each cistern was measured using a "laser distance measuring device". By the use of a laser beam technique, the 3D measurements viz. length $\mathrm{x}$ breadth $\mathrm{x}$ height were documented considering its location within the cave. On the basis of this data volume of each tank is calculated in litres. (Table 2) gives information about a systematic bifurcation of cave's tank relative to its capacity. This signifies the utility of cave and helps us to give a rough demographic idea of the cave with respect to the size of tank given to each cave. Based on the measurements plan of each cistern/tank was executed in Autocad civil 2018 software. This software is used by civil engineers and architects to draw the plans of architectures as per its dimensions.

\section{Table 2. Capacity frame in litres with reference to cave numbers}

\begin{tabular}{|c|c|}
\hline Capacity in litres & Cave numbers \\
\hline $100-1000$ & $16,23,33,38,92,98,99$ \\
\hline $1000-5000$ & $18,57,58,61,66,69,72$ \\
\hline $5000-10000$ & $2,3,8,21,22,27,51,60,63$ \\
\hline $10000-20000$ & $5,26,30,32,41,52,54,56,59,67$, \\
\hline & $69,73,90,93$ \\
\hline $20000-40000$ & $7,17,25,29,31,34,53,64,88$ \\
\hline $40000-60000$ & 11,65 \\
\hline $60000-80000$ & 10,9 \\
\hline
\end{tabular}


These plans revealed various shapes and sizes of cisterns underground. Most of the cisterns are categorized under rectangular and quadrangular shapes. Though few cisterns bears " $L$ shaped" and few are even of circular shapes. The circular shaped cisterns are few in quantity and are completely above the ground. Thus to acquire the volume of these cisterns, the diameter and depth were measured thoroughly (Table 3). The volume of all these circular cisterns revealed that they are less in capacity as compared to underground tanks. Based on the volume of tanks and its capacity it could be possible to calculate approximate demographic structure of this monastery. Such attempt shall be undertaken in the future research. Though the current water consumption in Mumbai metropolitan area could not be compared to the ancient Buddhist population, an experiment has been attempted to put the approximate demographic calculations in number. For this a standard of Bombay Municipal Corporation's method of calculating an average water use per person has been adopted in this study.

\section{Table. 3 Distribution of capacity in litres with reference to total number of caves}

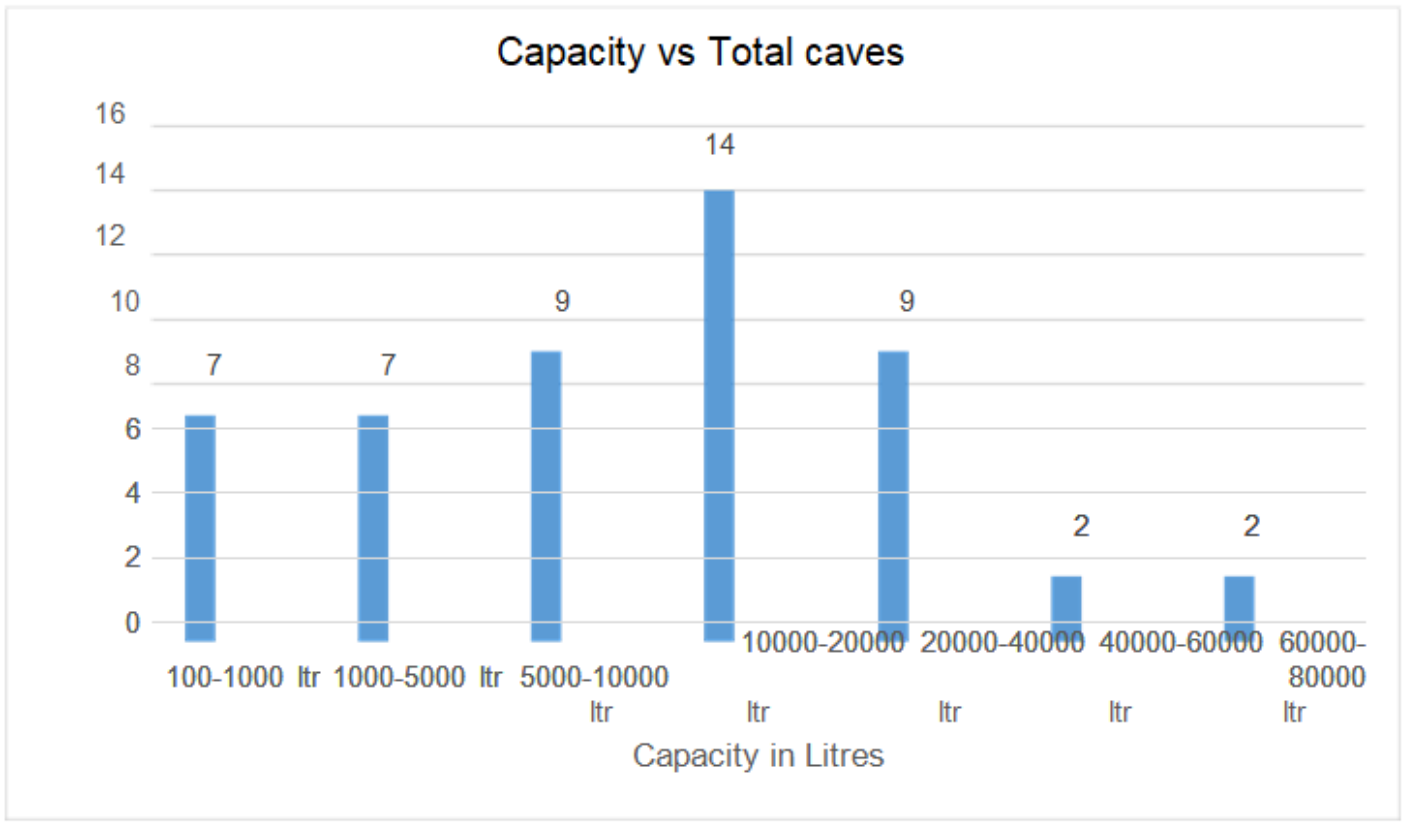

\section{SOURCES OF WATER TO TANKS}

The major source of water at Kanheri is rain water. This area where the site is located comes under moderate to heavy rainfall category. The water storage elements are recognized and divided into various categories like large tanks, small and large rectangular cisterns, quadrangular cisterns, small circular cisterns, Dam or Reservoir and water channels. These sources are further divided into following categories.

\subsection{Water Channels}

Most of the tanks have some sort of water channel carved out of rock which leads to tank (Fig.2). The system of eliminating wastage of water could be seen here. Sometimes the caves which had a faulty rock resulted in water leakage from the top of cave as seen in cave no. 50. The ancient engineers carved a channel through leakage portion and lead it to the mouth of water tank.

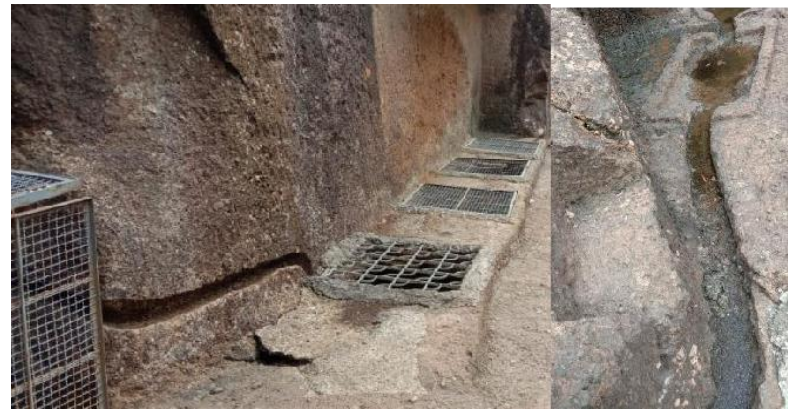

Fig. 2 Water channel leading to tank 


\subsection{Underground Water Springs}

The best example to this type of water source is cistern at right in cave no. 10. The cistern is carved in " $L$ Shaped" beneath the surface level. It could carry around 40,350 litres of water in it. This tank does not have any direct source of water visible from outside. The mouth of this cistern is covered with a canopy however, it does not have any water channel flowing in it. The unique phenomenon of this tank is that this tank is carved underground and the length of it is extended to the main water stream which is flowing between the top of the two mountains. Thus there is a possibility of a natural or manmade inlet being provided so as to allow the main stream water to fill the tank. (fig.3).

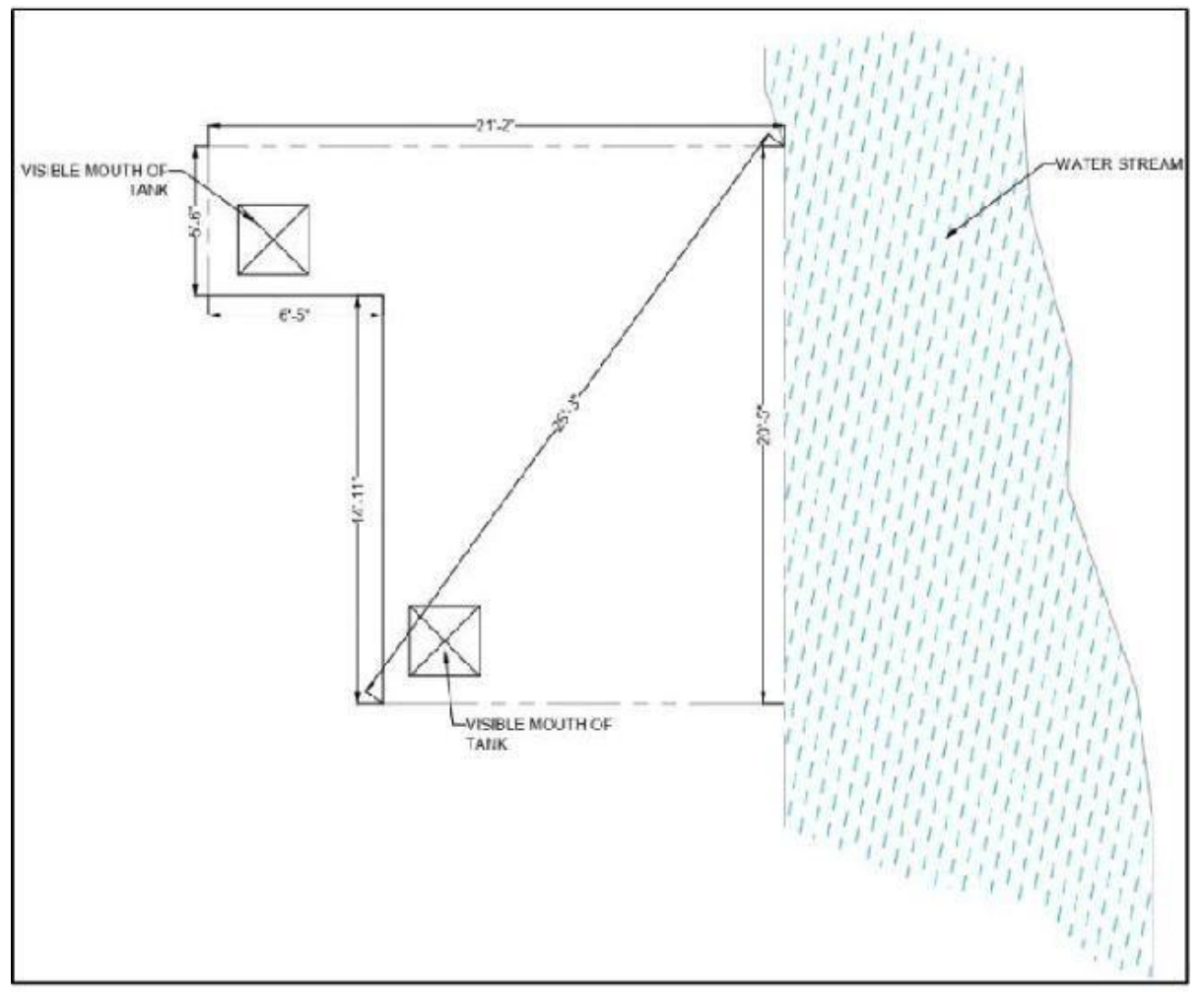

Fig. 3 Plan of water tank in cave no. 10

\subsection{Direct Rain Water}

The monastery has large open tanks on the top of both the hills. There are around 5 open tanks on the top of southern hill and one similar carved on the top of northern hill towards the eastern slope. All these tanks are large in size quite enough which hindered us to take the measurements. These tanks have stairs carved in it. Hypothetical purpose of these tanks could be common bathing area or even it could have been served as reserved water source during scarcity of water in any period of year.

\subsection{Reservoir}

The structure similar to dam or a large reservoir could be seen on the top at the junction of northern and the southern mountains. This dam like structure has been made a success by building two stone walls parallel to each other facing east west direction. The other two sides of the reservoir were naturally available in form of basalt of two mountains. Ancient engineers had converted this catchment area of this stream into a reservoir. The major source to fill this reservoir would have been direct rain water and certain amount of water flowing from slopes of mountain. To release the excess water in order to avoid the generation of water pressure on the walls, a small channel is carved out at the bottom left side of the back wall facing to east. This has converted a non-perennial water stream into a perennial one in form of reservoir. The stones used in the wall are well dressed ones and are filled with rubble and mortar between them [Pandit: 2010] (Fig. 4). Today the walls of this reservoir are in deteriorated condition. It was difficult to measure the exact measurements of the fragments of dam, though an attempt was made to collect the measurements of front wall. The front wall and the back wall are of same size measuring approximately $104.12 \times 9 \times 13 \mathrm{ft}$. On the basis of these dimensions along with the ruins of wall, a hypothetical drawing of wall has been illustrated in (Fig.5). 


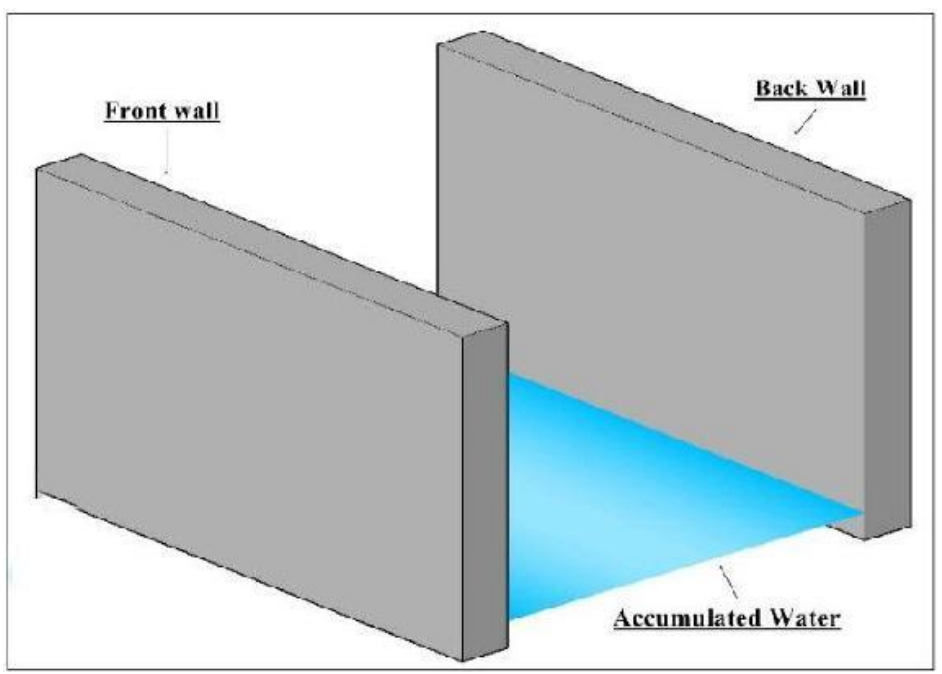

Fig. 4 Two constructed stone walls of Dam/ Reservoir

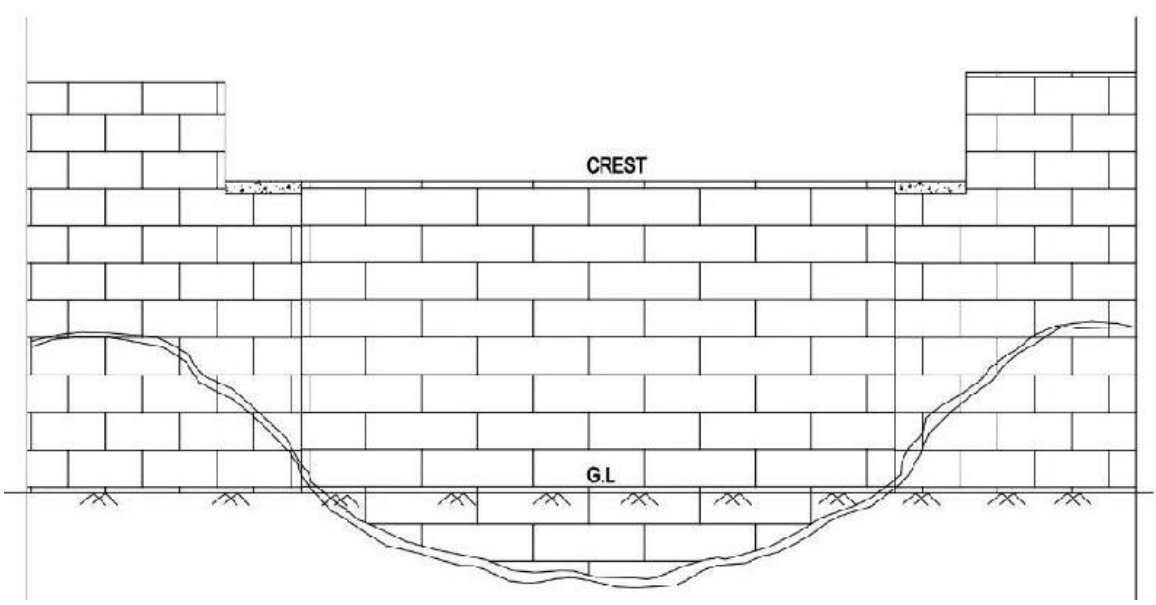

Fig. 5 Hypotherical reconstruction of reservoir's front wall

The tanks then were plotted on map along with the number of tanks each cave have (Fig.1). The caves such as cave no 11 which is known as Bhojana Mandapa due to 2 parallel benches running through the large rectangular hall at its center, have 2 tanks on both the sides of courtyard. The water capacity of right cistern is 38,416 litres and that of cistern in left is 18,996 litres respectively. This serves the purpose of serving large amount of water to a common hall which must have accommodated large population at a time. These two cisterns have specific cavities made for placing a wooden frame with lid on the mouths of tanks. (fig 6)

Similar cavities for wooden lid could be seen in cisterns of cave no. 64 and 90. It is made considering the approximate similar measurements to that of cave no.11. Thus it could be said that such wooden frame with the given measurements was the standard size of wooden lids at Kanheri.

Apart from this in cave no.53, the cistern's mouth has a step to reach the tank and there are three cavities carved, viz. two on the step and one below the step on surface level. The depth of these cavities measures $0.69 \mathrm{ft}, 0.3 \mathrm{ft}$ and 0.5 respectively. The tank measures $7.41 \times 11.10 \times 11.51 \mathrm{ft}$ in given dimensions relatively providing around 26,837 litres of capacity for storing water. This is considerably huge size of an underground tank. Considering the above given small cavities at near the tank's mouth suggests that there must have been some mechanism similar to pulley been used to access the water inside the tank. (Fig. 7) 


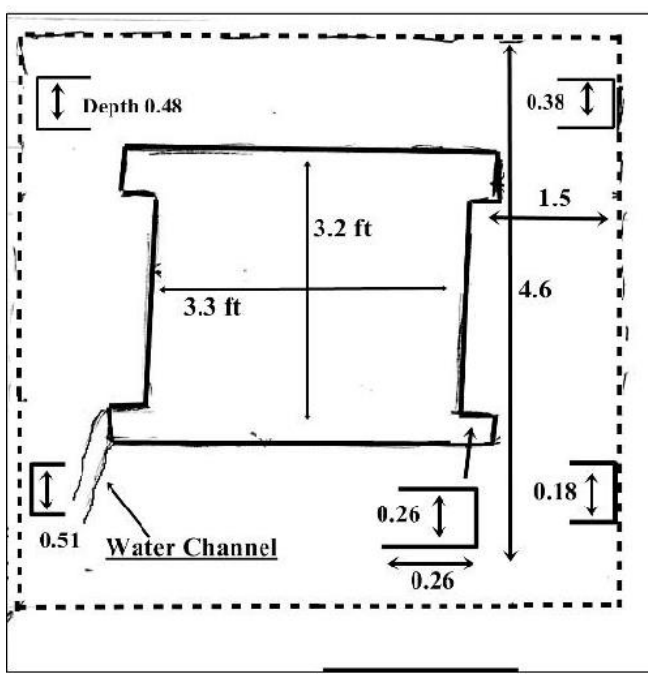

Fig. 6 Wooden Cavity made for lid of tank

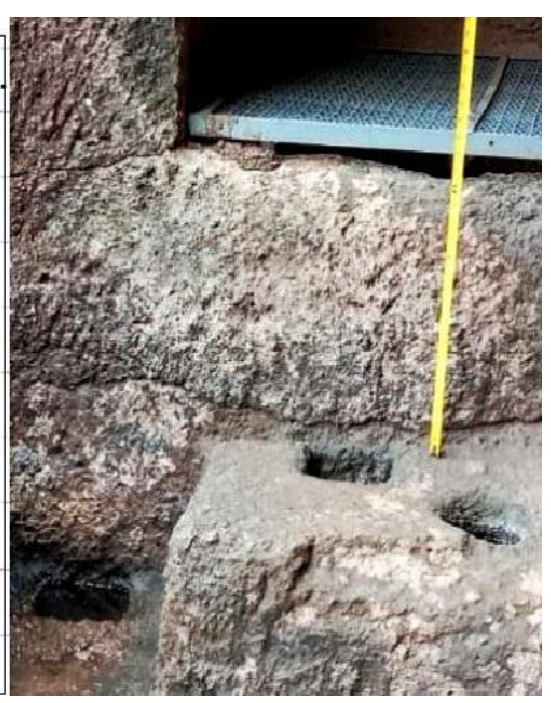

Fig.7 Manmade cavities

\section{EPIGRAPHICAL RELEVANCE}

The monastery of Kanheri was well habituated in its flourishing centuries is justified through increasing number of water conservation mechanism adopted revealed from the given data. It is possible to put the water cisterns in a particular time frame because of epigraphical evidences at the site. Some of the caves with cisterns has donative inscriptions mentioning the name of donor who made donations for that particular cistern. Cave no. 2 is one of the early cave and it has a record of donation of a cistern outside cave by person named svamidatta who hailed from Kalyan. A donour named Sulasadatta from Chemula (present day's Chaul near Alibag) who belonged to goldsmith family has donated a cistern outside the cave no.7. A significant evidence of construction of a big reservoir at the site could be revealed from the donation record of Sethi Punaka who hailed from Sopara. This inscription is carved in cave no. 41 which is facing at main water stream and is not far from the reservoir. Most of the laities had donated cave, halls, and cisterns together to the monastery as seen from the inscriptions in cave no. 54, 59, 64, 65 and 73 . A donour named Lavanika who hailed from Ambalika Vihara of Kalyan has donated a cave and a bathing tank at Kanheri. This inscription is located on the left wall of verandah of cave no. 75 .

\section{CURRENT WATER CONSUMPTION}

A number of factors like climate, culture, food habits, work and working conditions, level and type of development, and physiology determine the requirement of water. As per the Bureau of Indian Standards, IS: 1172-1993, a minimum water supply of $200 \mathrm{Ipcd}^{4}$ should be provided for domestic consumption in cities. (Shaban \& Sharma, 2007, 2191).

\subsection{Activity Wise Consumption of Water in Current Bombay}

At the household level, bathing consumes the highest amount of water, in all the seven cities, at about 28 per cent of total consumption. This is followed by consumption in toilets (20 per cent), washing clothes (18.6 per cent) and washing utensils (16.3 per cent). On an average, less than 10 per cent of the total water in a household is used for drinking and cooking. (Shaban \& Sharma, 2007, 2193).

Based on the above statistics, primarily an attempt was made to calculate the approximate demographic data of Kanheri in general irrespective of its cultural period. But such kind of calculations had its own limitations in form of inaccuracy of comparative study. It is not possible to make any assumptions using the current water usage with correlation to Kanheri's water usage in ancient India. The water consumption pattern of ancient Buddhist monks could not compare with today's water consumption in urban area like Bombay. Though a rough estimation has been drawn on the basis of above data which is discussed below.

\section{CONCLUSION}

The main water stream flowing through the southern and northern mountain indicates the creative knowledge of converting a non-perennial water body to perennial one by making use of mountain barriers and stone walls. Such kind of dam like structure must have supplied water to entire complex throughout the

\footnotetext{
${ }^{4}$ LPCD refers to litres per capita per day.
} 
year. The presence of member of plant family Cactaceae indicates a scarcity of water in this area. This particular plant commonly known as cactus, grows on a dry surface with lack of availability of water. This type of plant was spotted only on the top of both the mountains. This supports the hypothesis that despite of heavy rainfall, the water flows away through a non-perennial stream causing wastage of water. Thus the ancient engineers trapped the water into tanks and cisterns and turned the non-perennial water body into a perennial one.

The donatory records of construction cave and a cistern together at time makes it easier to assign the similar date to the cisterns. The caves that are located on the lower level of monastery gains the advantage of gravity in filling the tank. Thus it is one of the reasons that the capacity of these tanks is comparatively larger than that of cisterns on upper level. The main water stream turned out to be a perennial one due to this developed mechanism of water conservation. This water could have been utilized as important source for monastery through the rest of climatic year. Most of the underground tanks had a water channel as a source to fill them with water. The main water stream flowing through the southern and northern mountain indicates the creative knowledge of converting a nonperennial water body to perennial one by making use of mountain barriers and stone walls. Such kind of dam like structure must have supplied water to entire complex throughout the year.

The earlier tanks such as in cave no. 2 are open in nature allowing the rainwater directly to fill them. But later on a development could be seen in form of underground closed water tanks and water channels given to them significantly. Thus it can be said that caves of earlier centuries are mostly open and of basic type. But the later caves have well developed mechanism of hydro conservation. Apart from this the hypothetical use of pulley to large tanks and conversion of natural leakages to utilization added to the achievement of ancient engineers at site. Cave number 11 is termed as Bhojana Mandapa (Gokhale, 1991). This cave has a huge hall with two large stone benches running through its center. This cave has two underground tanks on both the sides of of entrance. These tanks has capacity to carry around 49000 litres of water altogether. Thus it would be significant to relate the presence of these tanks with relation to the heavy utility of cave number 11 . It would be not relevant to bring a demographic estimation on the basis of present day water consumption per person, but a Chinese monk named Fa Hien who travelled to India in $5^{\text {th }}$ century, writes about a five storied monastery hewn out of a large rock where monks resided could be relevant to none other than Kanheri. He also writes in his travelogue about the description of manmade perennial water stream and its utility by monks residing in adjoining cave from top layer to the bottom layer of mountain. This indicates that the majority of this engineering work was executed before Fa Hien's visit to India in $5^{\text {th }}$ Century C.E. As per the general regulations of Bombay Municipal Corporation, an average water consumption per person is 165 200 litres a day. This definitely gives us a vague idea of Kanheri's large population in its flourishing period. Similar to current situation, even in ancient times the water must have been a precious commodity. Thus an attempt to conserve and wisely utilize this commodity can be seen through their activity at Kanheri. Such kind of evidence of hydro resource management through application of engineering principles suggest a prevalence of administrative system at the ancient Buddhist cave complex of Kanheri.

\section{ACKNOWLEDGEMENTS}

My sincere thanks to Dr. Bipin Chandra Negi, Dy. Superintending Archaeologist, Mumbai Circle, A.S.I. for granting me permissions to conduct a survey at the site. Faithful thanks to Dr. Anuradha Ranade. Special thanks to Engr. Samruddhi More for the drawings she provided. I also thank Ms. Diksha Parkar for assisting me in the AutoCad software for execution of drawings. I also thank Ms. Deepali More for assisting me in documentation process.

\section{REFERENCE LIST}

Gokhale. S, (1991), Kanheri Inscriptions, Deccan College, Pune.

Garg. S, (2010), Hydrology \& Water Resources Engineering, Khanna Publication, Delhi, Vol. I.

Mitra, Debala (1971). Buddhist Monuments. Sahitya Samsad. Calcutta

Pandit. S, (2003), Kanheri: A Study in Its Sustained Patronage, Buddhism in Global Perspective, Vol. II, Somaiya Publication, Mumbai.

Pandit. S, (2010) Water Management System at Kanheri - Part I \& II, Journal of Asiatic Society of Mumbai, Vol. 83, p.p 27- 45.

Ray, H.P, (1994), The Archaeology of an Early Buddhist Pilgrimage Center in Western India, World 
Archaeology, Vol. 26, No. 1, Archaeology of Pilgrimage, p.p $35-46$.

Shaban. A \& Sharma.R, (2007), Water Consumption Patterns in Domestic Households in Major Cities, Economic and Political Weekly, pg. 2.

Shaw. J \& Sutcliffe J, (2003), Ancient Dams, Settlement Archaeology and Buddhist Propagation in Central India: The Hydrological Background., Journal of Hydrological Sciences, 48(2), p.p.277 - 291 